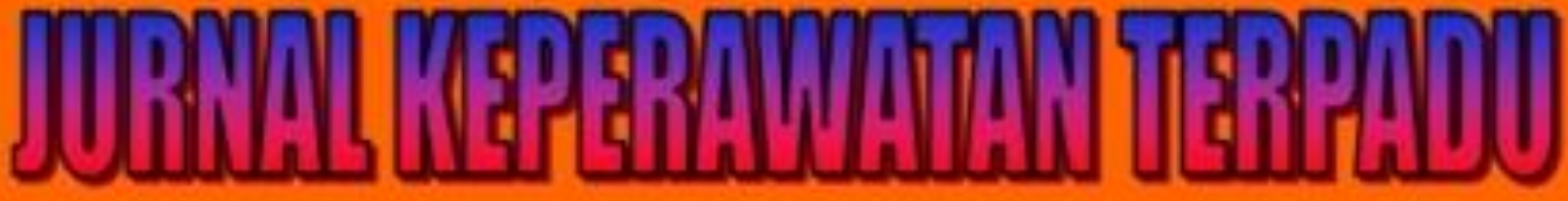

\section{Integrated Nursing Journal}

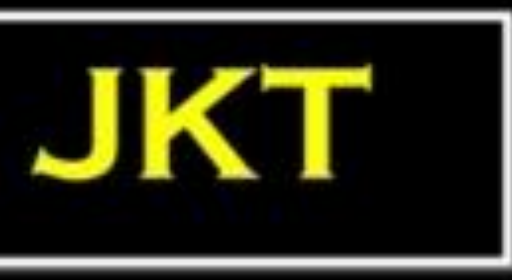

\section{p-ISSN: 2406-9698 (Print) e-ISSN: 2685-0710 (Online)}

\section{Vol. 2 No. 1 April 2020}

\section{KEMENTERIAN KESEHATAN RI}

\section{POLTEKKES MATARAM JURUSAN KEPERAWATAN}

Jalan Kesehatan V/10 Mataram NTB - http://jkt.poltekkes-mataram.ac.id 


\section{Vol. 2 No. 1 April 2020}

\section{Editorial Team}

\section{Editor-in-Chief}

Moh. Arip, Jurusan Keperawatan Poltekkes Kemenkes Mataram, Indonesia

\section{Editorial Board}

1. Mr. Frans Judea Samosir, Universitas Prima Indonesia, Indonesia

2. Baiq Kirana Kitna, Jurusan Keperawatan, Poltekkes Kemenkes Mataram, Indonesia

3. Irwan Budiana, Jurusan Keperawatan, Poltekkes Kemenkes Kupang, Indonesia

4. dr. Baskoro Tri Laksono, RS. Biomedika Mataram, Indonesia

5. Sitti Rusdianah, Jurusan Keperawatan, Poltekkes Kemenkes Mataram, Indonesia

6. Mira Utami Ningsih, Jurusan Keperawatan, Poltekkes Kemenkes Mataram, Indonesia

\section{Alamat Redaksi:}

Jurusan Keperawatan Mataram Poltekkes Kemenkes Mataram Kampus B

Jl. Kesehatan V No.10 Pajang Timur-Mataram NTB-Indonesia, 83127

Telepon: +62 370-621383

Fax: +62 370-631160

Email: jurnalkeperawatanterpadu2019@gmail.com

Laman: http://jkt.poltekkes-mataram.ac.id/index.php/home/index 


\section{Vol. 2, No. 1, April 2020}

\section{DAFTAR ISI}

Pengaruh Self Hypnosis Terhadap Respon Cemas Mahasiswa

Pada Ujian Tahap Akhir Program Di STIKes Buana Husada Ponorogo

Yudha Anggit Jiwantoro, Afifa Ika Kridawati, Danies Tunjung Pratiwi

Efektifitas Tepid Water Sponge Terhadap Penurunan Suhu Tubuh Pada Anak Dengan Masalah Keperawatan Hipertermia: Studi Kasus

Emy Mulyani, Nur Eni Lestari

Perilaku Pencegahan Penyakit Tidak Menular Pada Remaja Ambon

Hamdan Hariawan, Martini Tidore, Greeny Z. Rahakbau

Pengetahuan dan Sikap Perawat Berhubungan dengan Pelaksanaan Patient

Safety

Elisa Sulistia Fitri, Kusnanto, Herdina Maryanti

Efektivitas Art Therapy terhadap Pengetahuan dan Praktik Pemeliharaan Kesehatan Gigi pada Anak Usia Prasekolah

Linda Widyarani, Wiwi Kustio Priliana, Cecilya Kustanti

Konsep Diri Remaja Yang Mengalami Bullying

Puji Lestari, Liyanovitasari

Pengaruh Senam Tai Chi Terhadap Peningkatan Kualitas Tidur Lansia Di Balai Sosial Lanjut Usia Mandalika

Fathaillah Liestanto, Dina Fitriana

Hubungan Komunikasi Terapeutik Perawat Dengan Tingkat Kecemasan

Pasien Hemodialisa Di RSUD Dr Harjono Ponorogo

Ervan Nur Cholis, Rumpiati Rumpiati, Ike Sureni

Upaya Mengatasi Nyeri Post Op Sectio Cesaria Melalui Foot Massage Therapy Diruang Nifas RSUD Kota Mataram

Masadah, Cembun, Ridawati Sulaeman

Peningkatan Pemberdayaan Keluarga Melalui PINKESGA (Paket Informasi Keluarga) Kehamilan Dalam Mengambil Keputusan Merawat Ibu Hamil Mardiatun, Dewi Purnamawati, Ely Mawaddah
Page

$1-6$

Page

$7-14$

Page

$15-21$

Page

22-28

Page

29-39

Page

40-46

Page

$47-53$

Page

54-63

Page

$64-70$

Page

$70-78$ 


\title{
Efektifitas Tepid Water Sponge Terhadap Penurunan Suhu Tubuh Pada Anak Dengan Masalah Keperawatan Hipertermia: Studi Kasus
}

\author{
Emy Mulyani ${ }^{1}$, Nur Eni Lestari ${ }^{2}$ \\ ${ }^{1}$ Program Profesi Ners, Sekolah Tinggi Indonesia Maju, Indonesia \\ ${ }^{2}$ Sekolah Tinggi Indonesia Maju, Indonesia
}

\begin{abstract}
Abstrak
Hipertermia merupakan gejala yang paling sering muncul pada anak dengan Dengue Haemoragic Fever (DHF). Hipertermia dapat didefinisikan dengan suatu keadaan suhu tubuh di atas normal sebagai akibat peningkatan pusat pengatur suhu di hipotalamus. Pada anak yang mengalami demam peningkatan suhu ringan kisaran $37,5-38^{\circ} \mathrm{C}$. Dampak yang dapat ditimbulkan jika demam tidak ditangani adalah bisa menyebabkan kerusakan otak, hiperpireksia yang akan menyebabkan syok, epilepsi, retardasi mental atau ketidakmampuan belajar. Untuk mengatasi masalah hipertermia dapat dilakukan beberapa tindakan keperawatan mandiri yang bisa dilakukan, salah satunya yaitu Tepid Water Sponge (TWS). Tujuan penelitian ini yaitu untuk mengetahui efektifitas TWS sebagai intervensi dalam pemberian asuhan keperawatan pada anak dengan masalah hipertermia. Desain yang digunakan adalah studi kasus pada 2 kasus anak dengan masalah hipertermia. Hasil penelitian ini menunjukkan bahwa tindakan TWS mampu mengatasi masalah hipertermia pada anak. Hasil ini diharapkan dapat menjadi studi kasus manajemen hipertermia pada anak yang kemudian dapat dikembangkan menjadi penelitian dan landasan manajemen hipertermia pada anak.
\end{abstract}

Kata kunci: Dengue Haemoragic Fever, Hipertermia, Tepid Water Sponge

\begin{abstract}
Hyperthermia is the most common symptom in children who suffer from Dengue Haemoragic Fever (DHF). Hyperthermia can be defined by a state of body temperature above normal as a result of an increase in the temperature control center in the hypothalamus. In children who have a fever, a mild increase in temperature ranges from 37.5 to $38^{\circ} \mathrm{C}$. The impact that can be caused if the fever is not treated can cause brain damage, hyperpirexia which will cause shock, epilepsy, mental retardation or learning disabilities. To overcome hyperthermia problems, several independent nursing actions can be performed, one of which is Tepid Water Sponge (TWS). The purpose of this study was to identify the effect of nursing care using TWS in children with hyperthermia. The design used was a case study on 2 cases of children with hyperthermia problems. The results of this study showed that the Tepid Water Sponge action is able to overcome the problem of hyperthermia in children. This study is expected to be a case study of the management of hyperthermia in children which can then be developed into a research and management foundation for hyperthermia in children.
\end{abstract}

Keywords: Dengue Haemoragic Fever, Hyperthermia, Tepid Water Sponge 


\section{PENDAHULUAN}

Sehat dalam keperawatan anak adalah sehat dalam rentang sehat sakit. Sehat adalah keadaan kesejahteraan optimal antara fisik, mental, dan sosial yang harus dicapai sepanjang kehidupan anak dalam rangka mencapai tingkat pertumbuhan dan perkembangan yang optimal sesuai dengan usianya. Dengan demikian, apabila anak sakit akan dapat mempengaruhi pertumbuhan dan perkembangan fisik, psikologis, intelektual, dan spiritual (Supartini, 2012). Masalah kesehatan yang sering ditemukan dan sering menjadi keluhan oleh orangtua mulai dipraktik dokter sampai dengan unit gawat darurat (UGD) pada anak adalah demam yang meliputi 10-30 \% dari jumlah kunjungan (Kania, 2007).

Masalah demam sudah menjadi fokus perhatian tersendiri pada berbagai profesi kesehatan baik itu dokter, perawat, dan bidan. Bagi profesi perawat masalah gangguan suhu tubuh atau perubahan suhu tubuh termasuk demam sudah dirumuskan secara jelas pada North Nursing Association (Sodikin, 2012). Demam dapat didefinisikan dengan suatu keadaan suhu tubuh di atas normal sebagai akibat peningkatan pusat pengatur suhu di hipotalamus. Pada anak yang mengalami peningkatan suhu ringan yaitu kisaran $37,5^{\circ} \mathrm{C}-38^{\circ} \mathrm{C}$ (Sodikin, 2012). Demam dapat membahayakan apabila timbul peningkatan suhu yang tinggi. Dampak yang dapat ditimbulkan jika demam tidak ditangani bisa menyebabkan kerusakan otak, hiperpireksia yang akan menyebabkan syok, epilepsi, retardasi mental atau ketidakmampuan belajar (Marcdante dkk., 2014).

Suhu tubuh pada kondisi meningkat dapat dipergunakan sebagai salah satu ukuran penting yang dapat memberikan petunjuk mengenai memburuk atau membaiknya keadaan penderita. Demam merupakan suatu pertanda adanya gangguan kesehatan dan hanyalah suatu keluhan dan bukan merupakan suatu diagnosis. Sebagai suatu keluhan demam merupakan keluhan kedua terbanyak setelah nyeri, jadi merupakan suatu hal yang sangat penting untuk diketahui tentang demam (Hastomo \& Suryadi, 2018; Lestari, 2018; Marcdante dkk., 2014).

Badan Kesehatan Dunia (WHO) mengemukakan jumlah kasus demam pada anak usia balita di seluruh dunia mencapai 18-34 juta, anak merupakan yang paling rentan terkena demam, walaupun gejala yang dialami anak lebih ringan dari dewasa (Wardiyah dkk., 2016). Dari hasil survey Departemen Kesehatan RI, frekuensi kejadian demam menjadi 15,4 per 10.000 penduduk. Survey berbagai rumah sakit di Indonesia memperlihatkan peningkatan jumlah penderita. Sedangkan Kasus DHF pada tahun 2018 berjumlah 65.602 kasus, dengan jumlah kematian sebanyak 467 orang. Jumlah tersebut menurun dari tahun sebelumnya, yaitu 68.407 kasus dan jumlah kematian sebanyak 493 orang. Angka kesakitan DHF tahun 2018 menurun dibandingkan tahun 2017, yaitu dari 26,10 menjadi 24,75 per 100.000 penduduk. Penurunan case fatality rate (CFR) dari tahun sebelumnya tidak terlalu tinggi, yaitu 0,72\% pada tahun 2017, menjadi 0,71\% pada tahun 2018 (Kemenkes RI, 2019). 
Peningkatan suhu tubuh pada balita sangat berpengaruh terhadap fisiologis organ tubuhnya. Hal tersebut terjadi karena luas permukaan tubuh relatif kecil dibandingkan pada orang dewasa, menyebabkan ketidakseimbangan organ tubuhnya. Selain itu pada balita belum terjadi kematangan mekanisme pengaturan suhu sehingga dapat terjadi perubahan suhu yang cepat terhadap lingkungan. Kegawatan yang dapat terjadi ketika demam tidak segera diatasi dan suhu tubuh meningkat terlalu tinggi yaitu dapat menyebabkan dehidrasi, latergi, penurunan nafsu makan sehingga asupan nutrisi berkurang, dan kejang yang mengancam kelangsungan hidup anak (Marcdante dkk., 2014).

Demam berkepanjangan masih menjadi masalah morbiditas dan mortalitas di negara-negara tropis dan berkembang. Demam persisten atau demam berkepanjangan adalah demam yang berlangsung lebih dari delapan hari perawatan di rumah sakit, dan terkadang gagal mendeteksi penyebab demam (Latupeirissa, 2012). Hasil penelitian Bakry dkk. (2008), yang dilakukan pada 100 pasien anak di RSCM menjelaskan bahwa penyakit infeksi merupakan penyebab terbanyak demam pada anak yaitu 80 anak (80\%) dari seluruh kasus, diikuti dengan penyakit kolagen - vascular 6 anak (6\%), penyakit keganasan 5 anak (5\%), serta tidak terdiagnosis 9 anak (9\%).

Bakry juga memaparkan bahwa sebagian besar pasien demam adalah laki-laki 59\% sedangkan wanita hanya $41 \%$. Berdasarkan kelompok usia, penderita demam terbanyak adalah kelompok usia dibawah 2 tahun sebanyak 35 anak (35\%), sedangkan kelompok usia diatas 6 tahun sejumlah 19 anak (19\%) kasus. Durasi demam berkepanjangan terbanyak pada pasien yang dirawat di RSUPN Dr. Cipto Mangunkusumo adalah 8-30 hari.

Demam memerlukan perawatan lebih lanjut, yaitu dengan menjaga agar demam yang terjadi tidak meningkat, sehingga kemungkinan anak mengalami kejang demam dan dehidrasi dapat dihindari. Terapi non farmakologi untuk demam menggunakan metode yang meningkatkan pengeluaran panas melalui evaporasi, konduksi, konveksi, dan radiasi. Secara tradisional perawat telah menggunakan mandi tepid water sponge, yaitu dengan menggunakan air hangat (Perry \& Potter, 2010). Perawatan anak demam dilakukan dengan berbagai tindakan, seperti pemberian obat penurun panas (farmakologi), pemberian cairan air yang lebih banyak dari biasanya (manajemen cairan), penggunaan pakaian yang menyerap keringat, dan melakukan tepid water sponge (Sodikin, 2012).

Tepid water sponge merupakan suatu metode pemandian tubuh yang dilakukan dengan cara mengelap sekujur tubuh yang dilakukan dengan cara mengelap sekujur tubuh dan melakukan kompres pada bagian tubuh tertentu dengan menggunakan air yang suhunya hangat untuk jangka waktu tertentu (Perry \& Potter, 2010). Pada saat pemberian tepid water sponge otak akan menyangka bahwa suhu diluar panas, sehingga otak akan segera memproduksi dingin dan terjadilah penurunan suhu tubuh. dengan kompres hangat pada daerah vaskuler yang banyak, maka akan memperluas daerah yang mengalami vasodilatasi. Vasodilatasi yang kuat pada kulit akan memungkinkan percepatan perpindahan panas dari tubuh kekulit, hingga delapan kali lipat lebih banyak (Tamsuri, 2007).

Tepid water sponge dilakukan apabila suhu diatas $38,5^{\circ} \mathrm{C}$ dan telah mengkonsumsi antipiretik setengah jam sebelumnya. Suhu air untuk kompres antara $30^{\circ}-35^{\circ} \mathrm{C}$, untuk pelaksanaannya 
dilakukan dalam waktu 15 sampai 20 menit dalam 1 kali pelaksanan. Panas dari kompres tersebut merangsang vasodilatasi sehingga mempercepat proses evaporasi dan konduksi, yang pada akhirnya dapat menurunkan suhu tubuh (Alves \& Almeida 2008 dalam Setiawati, 2009).

Pemberian terapi tepid water sponge disertai antipiretik dapat lebih menurunkan suhu tubuh pada pasien demam dibandingkan dengan antipiretik saja. Hal ini dibuktikan dengan penelitian yang dilakukan oleh Setiawati dkk. (2009) menunjukan bahwa pada menit ke 5 setelah minum antipiretik, rata-rata penurunan suhu tubuh pada anak penderita demam yang mendapat antipiretik ditambah tepid water sponge adalah sebesar $1,3^{\circ} \mathrm{C}$. Sedangkan pada kelompok anak yang hanya minum antipiretik tanpa pemberian tepid water sponge, penurunan suhu tubuh rata-rata setelah 30 menit setelah minum antipiretik sebesar $0,63^{\circ} \mathrm{C}$. Hal ini menunjukan bahwa lebih besarnya penurunan suhu tubuh pada anak dengan pemberian tepid water sponge.

\section{METODE PENELITIAN}

Penelitian ini menggunakan desain studi kasus pada 2 kasus anak dengan masalah hipertermia. Penelitian dilakukan di ruang rawat inap anak RS PMI Bogor. Penelitian ini dilakukan pada bulan Maret 2019 sampai dengan April 2019. Sampel dalam penelitian ini adalah anak yang dirawat dengan diagnosis medis DHF yang mengalami masalah keperawatan hipertermia. Pengumpulan data dilakukan dengan mencatat catatan medis dan catatan keperawatan pasien yang mendapat intervensi TWS serta dengan melakukan pemeriksaan fisik dan observasi langsung terhadap pasien tersebut. Pemberian TWS dilakukan sesuai dengan prosedur operasional pemberian TWS. TWS diberikan 20-30 menit setelah diberikan antipiretik. Evaluasi efek TWS terhadap masalah keperawatan hipertemia pada anak dilakukan setelah dilakukan tindakan tepid water sponge pada 20 30 menit setelah pemberian antpiretik. Evaluasi ini dilakukan melalui wawancara terhadap orangtua dan pasien langsung. Analisis terhadap masalah hipertermia dilakukan dengan mengidentifikasi peningkatan suhu tubuh tubuh, perubahan warna kulit dan adanya tanda gejala dehidrasi.

\section{HASIL PENELITIAN}

Kasus 1, An. SL, Pasien yang pertama bernama An. SL, usia 10 Tahun, berjenis kelamin perempuan. Pasien masuk rawat di RS pada tanggal 11 Maret 2019 jam 10.00 wib, dan pengkajian dilakukan pada tanggal 11 Maret 2019 jam 14.30 wib. Diagnosis medis saat masuk adalah DHF. Keluhan utama pasien saat dikaji adalah demam, ibu pasien mengatakan pasien demam sejak hari Jumat sore setelah pasien pulang sekolah. Pasien mengeluh mual dan sempat muntah-muntah sebanyak 5 kali. Pasien juga mengeluh sakit di ulu hati. Badan badan juga terasa ngilu. Akhirnya pasien dibawa ke Rumah Sakit oleh keluarga. Pasien pernah dirawat di Rumah Sakit Salak pada saat pasien berusia 3 tahun karena Diare.

Pada saat dilakukan pemeriksaan tanda-tanda vital didapatkan hasil Tekanan Darah 100/60mmHg, Nadi $124 \mathrm{x} / \mathrm{menit}$, suhu $39,5^{\circ} \mathrm{C}$, frekuensi nafas $28 \mathrm{x} / \mathrm{menit}$. Asupan makanan sedikit 
berkurang karena pasien mengeluh mual terutama ketika akan makan dan minum serta tidak ada selera untuk makan. Sebelum sakit pasien mengkonsumsi makanan lunak yang disedikan keluarga, demikian juga saat di rumah sakit, pasien makan makanan lunak, pasien hanya menghabiskan 4 sendok makan. Untuk cairan, sebelum sakit pasien minum 6-7 gelas sehari. Selama sakit pasien mengeluh malas untuk minum oleh karena mual. Pasien minum 4-5 gelas sehari.

Kasus 2, An. A, Pasien yang kedua bernama An. A, usia 3 Tahun, berjenis kelamin perempuan. Pasien masuk rawat di RS pada tanggal 11 Maret 2019 jam 23.05 wib, dan pengkajian dilakukan pada tanggal 12 Maret 2019 jam 14.30 wib. Diagnosis medis saat masuk adalah DHF. Keluhan utama pasien saat dikaji adalah demam, ibu pasien mengatakan pasien mulai demam dan pusing sejak dua hari yang lalu sebelum masuk rumah sakit. Badan terasa sakit, lemas, mual, muntah setiap kali mau makan, muntah disertai dengan darah sedikit bercampur lendir sebanyak dua kali, mimisan satu kali. Kemudian pasien dibawa ke rumah sakit oleh keluarga.

Pada saat dilakukan pemeriksaan tanda-tanda vital didapatkan hasil Tekanan Darah 100/70mmHg, Nadi $124 \mathrm{x} /$ menit, frekuensi nafas 28x/menit, suhu 38,8 $8^{\circ} \mathrm{C}$. Asupan makanan berkurang karena pasien tidak ada selera untuk makan dan muntah setiap kali makan dan minum. Pasien mengkonsumsi makanan lunak yang disediakan keluarga pada saat di rumah. Pada saat di Rumah Sakit, pasien juga pendapat makanan lunak dan hanya menghabiskan 4 sendok makan dari porsi makanan yang diberikan. Sebelum sakit, asupan cairan pasien didapat dari minum 6-7 gelas air sehari dan dari sayuran dan makanan lain yang dikonsumsi. Selama sakit pasien tampak tidak mau minum. Asupan cairan dari minum berkurang karena pasien hanya minum 4-5 gelas sehari.

Pada kasus pertama An SL, pada hari pertama tindakan tepid water sponge dilakukan sebanyak 2 kali. Tindakan ini dilakukan karena 2 jam setelah dilakukan tindakan, suhu tubuh klien masih diatas $38^{\circ} \mathrm{C}$. Sehingga dilakukan kembali tindakan pemberian TWS. Selama diberikan tindakan, klien kooperatif dan tampak tenang. Setelah dilakukan intervensi pemberian TWS selama $2 \mathrm{x} 2 \mathrm{jam}$, terjadi penurunan suhu tubuh sebanyak $2^{\circ} \mathrm{C}$. Pada hari kedua, tindakan tepid water sponge, klien kembali mengalami hipertermi dengan suhu $38,4^{\circ} \mathrm{C}$. Pada hari kedua dilakukan kembali pemberian TWS sebanyak 2 kali dengan dan didapatkan penurunan suhu $2^{\circ} \mathrm{C}$ setelah dilakukan intervensi TWS selama $2 \times 2$ jam. Pada hari ketiga tindakan tepid water sponge dilakukan hanya 1 kali karena 2 jam setelah dilakukan intervensi TWS suhu tubuh klien yang semula $38,7^{\circ} \mathrm{C}$ sudah turun menjadi $37,3^{\circ} \mathrm{C}$. Pemberian TWS pada hari ketiga juga berjalan dengan baik, klien kooperatif dan tenang. Rata-rata penurunan suhu tubuh pada pasien kedua adalah $2^{\circ} \mathrm{C}$.

Pada kasus kedua, pada hari pertama tindakan tepid water sponge dilakukan sebanyak 2 kali. Tindakan ini dilakukan karena 2 jam setelah dilakukan tindakan, suhu tubuh klien masih diatas $38^{\circ} \mathrm{C}$. Sehingga dilakukan kembali tindakan pemberian TWS. Selama diberikan tindakan, klien kurang kooperatif, rewel dan menangis. Setelah dilakukan intervensi pemberian TWS selama 2x 2 jam, terjadi penurunan suhu tubuh sebanyak $1^{\circ} \mathrm{C}$, dari suhu awal $38,3^{\circ} \mathrm{C}$ menjadi $37,3^{\circ} \mathrm{C}$. Pada hari kedua, tindakan tepid water sponge, klien kembali mengalami hipertermi dengan suhu $38,6^{\circ} \mathrm{C}$. Pada 
hari kedua dilakukan kembali pemberian TWS sebanyak 2 kali dengan dan didapatkan penurunan suhu $1^{\circ} \mathrm{C}$ menjadi $37,6^{\circ} \mathrm{C}$ setelah dilakukan intervensi TWS selama $2 \times 2$ jam. Pada hari kedua, pemberian TWS, klien lebih kooperatif dan tidak rewel. Pada hari ketiga tindakan tepid water sponge hanya dilakukan 1 kali. Suhu tubuh klien menjadi $37^{\circ} \mathrm{C}$ setelah 1 × 2 jam dilakukan tindakan TWS. Suhu ini turun $1{ }^{\circ} \mathrm{C}$ dari suhu awal $38^{\circ} \mathrm{C}$. Rata-rata penurunan suhu tubuh pada pasien kedua adalah $1{ }^{\circ} \mathrm{C}$.

\section{PEMBAHASAN}

Pada kasus 1 An. SL, perempuan, usia 10 tahun mengalami masalah hipertermia dengan suhu $39,5^{\circ} \mathrm{C}$. Kasus 2 An. A, perempuan, usia 3 tahun mengalami masalah hipertermia dengan suhu $38,8^{\circ} \mathrm{C}$. Semua pasien dalam kasus kelolaan ini tidak mengalami kekurangan cairan.

Berdasarkan analisis hasil pengkajian didapatkan bahwa hipertermia merupakan masalah yang menjadi prioritas utama, Pada kasus pertama dan kedua sama-sama mengalami masalah utama hipertermia. Berdasarkan pengkajian yang telah dilakukan pada kasus pertama dan kedua hipertermia disebabkan oleh penyakit infeksi virus dengue.

Keluhan hipertermia yang dirasakan klien sama, hal tersebut terjadi oleh karena pada klien yang menderita DHF akan terjadi infeksi virus dengue sehingga terjadi proses inflamasi, yang menyebabkan aktivasi interleukin 1 di hipotalamus untuk memacu pengeluaran prostaglandin, akibatnya akan terjadi peningkatan kerja thermostat. Hal tersebutlah yang dapat menyebabkan terjadinya hipertermia (Sodikin, 2012).

Intervensi keperawatan yang dapat dilakukan untuk mengatasi masalah keperawatan hipertermia dapat dilakukan tindakan mandiri oleh perawat, salah satunya dengan pemberian tepid water sponge. Tepid water sponge adalah sebuah teknik kompres hangat yang menggabungkan tekhnik kompres blok pada pembuluh darah supervisialis dengan tekhnik seka. Pada proses tindakan tepid water sponge ini mekanisme kerja pada tindakan tersebut memberikan efek adanya penyaluran sinyal ke hipotalamus melalui keringat dan vasodilatasi perifer sehingga proses perpindahan panas yang diperoleh dari tindakan tepid water sponge (Sodikin, 2012).

Hal ini berlangsung melalui dua proses yaitu konduksi dan evaporasi dimana proses perpindahan panas melalui proses konduksi ini di mulai dari tindakan mengkompres anak dengan waslap dan proses evaporasi diperoleh dari adanya seka pada tubuh saat pengusapan yang dilakukan sehingga terjadi proses penguapan panas menjadi keringat (Sodikin, 2012).

Pendekatan farmakologis dapat dilakukan dengan pemberian obat-obatan antipiretik. Sedangkan secara non farmakologis melalui pemberian cairan air yang lebih banyak dari biasanya (manajemen cairan), penggunaan pakaian yang menyerap keringat, dan melakukan tepid water sponge (Sodikin, 2012). Intervensi dilakukan pada pasien dengan hipertermia berupa tekhnik tepid water sponge yang mana tindakan ini dilakukan dengan cara perpaduan antara menyeka tubuh pasien dan dengan memberikan kompres hangat selama 15-20 menit dipembuluh besar pasien. 
Pada penurunan suhu tubuh antara klien pertama dan kedua terdapat perbedaan sebesar $1^{\circ} \mathrm{C}$. Hal tersebut bisa terjadi oleh karena ada beberapa hal yang bisa mempengaruhi penurunan suhu tubuh salah satunya yaitu faktor umur klien. Usia merupakan salah satu faktor yang mempengaruhi suhu tubuh (Hegner, 2003). Yang mana umur pasien kedua An. A berusia 3 tahun dibawah dari umur pasien pertama An. SL berusia 10 tahun. Anak dengan umurnya lebih besar atau tinggi badan atau berat badan lebih, memiliki permukaan tubuh yang lebih luas. Pada saat tindakan tepid water sponge dilakukan pengusapan waslap keseluruh permukaan tubuh anak, semakin luas permukaan tubuh anak semakin luas kulit yang kontak dengan waslap dan air hangat sehingga pelepasan panas baik melalui cara evaporasi maupun konveksi bisa lebih optimal (Suryadi \& Yuliani, 2010).

Adapun faktor lain yang bisa mempengaruhi penurunan suhu tubuh adalah faktor suhu lingkungan dan tingkat stres klien saat tindakan dilakukan. Pada faktor suhu dan lingkungan, bila suhu lingkungan lebih rendah dari suhu tubuh maka hypothalamus posterior merepon dengan meningkatkan produksi panas melalui peningkatan metabolism dan aktifitas otot rangka dalam bentuk menggigil. Bila suhu lingkungan lebih tinggi dari suhu tubuh maka hypothalamus anterior merespon dengan meningkatkan pengeluaran panas melalui vasodilatasi kulit dan menambah produksi keringat. Selain itu pakaian yang digunakan oleh pasien sangat berpengaruh terhadap penurunan suhu tubuh. Dalam hal ini kedua pasien sama-sama menggunakan pakaian yang tipis sehingga mempengaruhi penurunan suhu tubuh .

Pada kondisi stres fisik dan emosi dapat meningkatkan suhu tubuh melalui stimulasi hormonal dan persyarafan. Perubahan fisiologi tersebut yang dapat meningkatkan panas. Klien yang cemas pada saat tindakan dilakukan suhu tubuhnya akan lebih tinggi dari normal (Wong, dkk. 2008). Namun demikian pada kedua kasus tersebut sama-sama terjadi penurunan suhu tubuh, yang berarti bahwa tindakan Tepid Water Sponge efektif sehingga dapat dijadikan sebagai salah satu tindakan non farmakologi yang dapat dilakukan perawat dalam mengatasi demam pada anak.

Implikasi asuhan keperawatan yang dilakukan pada klien dengan masalah keperawatan hipertermia akan berdampak bagi perawat dan klien. Peran perawat dalam melakukan tindakan mandiri kepada klien akan membantu mengatasi masalah yang dialami oleh klien (Purwanti dan Winarsih, 2008). Salah satu tindakan mandiri yang bisa dilakukan oleh perawat adalah dengan memberikan tepid water sponge pada klien dengan hipertermia. Dengan pemberian tindakan tepid water sponge yang sesuai dengan prosedur yang ada, maka hasil yang diharapkan kepada klien akan dapat dicapai secara optimal.

\section{KESIMPULAN}

Pada pengkajian klien pertama dan kedua didapatkan adanya peningkatan suhu tubuh dan masalah keperawatan hipertermia. Intervensi keperawatan mandiri yang bisa dilakukan oleh perawat salah satunya yaitu dengan memberikan tepid water sponge. Pada dua klien yang dilakukan teknik tepid water sponge terbukti dapat menurunkan demam. Terdapat perbedaan penurunan suhu tubuh 
antara kedua klien yang tidak signifikan setelah dilakukan tindakan tepid water sponge yaitu sebesar $0,2^{\circ} \mathrm{C}$. Hal ini dapat dipengaruhi oleh beberapa faktor penurunan suhu tubuh yaitu faktor usia klien. Yang mana kasus pertama berusia 10 tahun dan kasus kedua berusia 3 tahun.

\section{DAFTAR PUSTAKA}

Alves, J.G.B, Almeida, N.D.C.M., \& Almeida, C.D.C.M. (2008). Tepid sponging plus dipyrone versus dipyrone alone in reducing body temperature in febrile children. Sao Paulo Medical Journal. 126(2): 107-111.

Hastomo, M.T., \& Suryadi, B. (2018). Teknik relaksasi nafas dalam terhadap skala nyeri pada saat pemasangan infus di Instalasi Gawat Darurat. Jurnal Ilmiah Ilmu Keperawatan Indonesia. 8(2): 436-442. https://doi.org/10.33221/jiiki.v8i02.320

Kania, N. (2007). Penatalaksanaan demam pada anak. Bandung: Unpad.

Latupeirissa, D. (2012). Demam berkepanjangan pada anak di RSUP Fatmawati tahun 2008-2010. Sari Pediatri. 14(4): 241-5

Lestari, N.E. (2018). Telaah Kepustakaan: Penurunan Tingkat Nyeri Menggunakan Terapi Musik Pada Anak Usia Prasekolah yang Dilakukan Pemasangan Infus. Jurnal Keperawatan Dan Kebidanan Keris Husada. 2(1): 25-30.

Marcdante, K.J., Kliegman, R.M., Jenson, H.B., \& Behrman, R.E. (2014). Nelson ilmu kesehatan anak esensial. Jakarta: Saunders Elsevier.

Potter, P.A \& Perry A.G. (2012). Fundamental of nursing: Fundamental keperawatan. Jakarta: Salemba Medika.

Purwanti, S., \& Winarsih, N. A. (2008). Pengaruh kompres hangat terhadap suhu tubuh pada pasien anak hipertermia di ruang rawat inap RSUD dr. Moewardi Surakarta.

Sodikin. (2012). Prinsip perawatan demam pada anak. Jakarta: Rufaida LQ.

Supartini. (2012). Buku ajar konsep dasar keperawatan anak. Jakarta: EGC

Suryadi \& Yuliani. (2010). Asuhan keperawatan pada anak. Jakarta: EGC

Tamsuri. (2007). Tanda-tanda vital suhu tubuh. Jakarta: EGC.

WHO. (2008). regional guidelines on dengue/ DHF prevention and control. dengue in Indonesia. Diakses dari http://www.searo.who.int/

Wardiyah, A., Setiawati, S., \& Setiawan, D. (2016). Perbandingan efektifitas pemberian kompres hangat dan tepid sponge terhadap penurunan suhu tubuh anak yang mengalami demam RSUD Dr. H. Abdul Moeloek Provinsi Lampung. Jurnal Ilmu Keperawatan. 4(1):44-56.

Wong, D.L., Marilyn, H.E., David, W., Marilyn, L.W., \& Patricia, S. (2008). Buku ajar keperawatan pediatrik wong. Volume 1. ( $6^{\text {th }}$ ed.). Jakarta: EGC 